\title{
M R S: THE CORPORATE ROLE
}

As all those familiar with MRS meetings are aware, the Society enjoys the participation of researchers from industry, government and university laboratories as attendees and authors as well as in the program planning effort. The support of MRS activities by individuals and their institutions in this way has been an invaluable asset and insures the continuing vitality of our interdisciplinary forum. Perhaps less well known is the means by which the MRS is financially supported.

Each topical symposium offered by the Society operates as a quasiautonomous conference in its own right and incurs most of the usual expenses. The single meeting registration fee and members' dues do not cover the cost of some fourteen symposia each year and provide for year-round Society operations. Major governmental grants directed toward specific symposium topics of interest to various Federal agencies have contributed to closing this gap. Past meetings have been supported by the Office of Naval Research, the Army Research Office, the Air Force Office for Scientific Research, the Defense Advanced Research Projects Agency, the Department of Energy, the Nuclear Regulatory Commission, the National Aeronautics and Space Administration, and the U.S. Bureau of Mines. We trust that, to the extent our topical coverage overlaps the missions of these agencies, continued support will be forthcoming.

As the Society's programs continue to expand in size and scope, additional support will be required. This need becomes particularly acute in times of reduced governmental spending. The technological relevance of MRS symposia accounts for the strong representation of industrial laboratories at our meetings. This is reinforced by the interdisciplinary format of the meetings, which so closely parallels the way materials research is actually pursued. An increasing number of industrial research and commercial organizations have recognized the Society's need for support beyond that accrued from meeting registration fees and have sponsored some MRS activities. To aid in developing a close liaison with our corporate sponsors and to help enlist the support of additional sponsors, the Council of the MRS formed the Corporate Participation Committee, which first met in November 1980.

Over the past fifteen moths the Committee has worked toward expanding corporate sponsorship through a variety of means, not the least of which has been through individual researchers from the industrial community. Of course, the primary benefit to sponsoring corporations is, and will continue to be, the opportunity for technical and personal interactions and information exchange which MRS meetings provide. Beyond this, our corporate sponsors are given advance notice of Society activities and their advice is directly solicited in the planning stage of topical programs. They are also given the option of providing literature displays for participants at MRS meetings.

It is also well recognized that the interaction between university and industry at our meetings is mutually beneficial. Not only does each segment of the research community learn of the interests and activities of the other, but personal contacts are an effective means by which industry can identify talented researchers as prospective staff members for industrial research labs. The MRS will facilitate this process by providing the appropriate liaison and interview mechanisms at the request of a sponsoring corporation.

Corporations that affiliate with the
Society through sponsorship of particular topical symposia or through general grants-in-aid are encouraged to send representatives to MRS meetings. The Corporate Participation Committee schedules Corporate Affiliate functions where matters of mutual concern are discussed among our affiliates and with Society officers. Listed below are companies presently supporting the MRS.

\section{CORPORATE SPONSORS}

Allied Corporation

Atlantic Cement Co.

Bell Laboratories

Canberra Industries

Coherent

E. I. DuPont de Nemours \& Co.

Eastman Kodak Co.

Elsevier North-Holland Publishing Co.

Exxon Research and Engineering Co.

General Electric Co.

GTE Laboratories

Helionetics

International Business Machines Corp.

JEC Lasers

Martin Marietta Laboratories

Quantronix Corporation

Sandia National Laboratories

Spectra Physics

Springer-Verlag New York

Tachisto

United Technologies Research

Center

UOP

W. R. Grace \& Co.

Inquires regarding sponsorship may be directed to the MRS Secretariat. 